\title{
Evolution of Cultural Clusters in China: Comparative Study of Beijing and Shanghai
}

\author{
Jun Wang \\ Assistant Professor of David Lam Institute for East-West Studies, Hong Kong Baptist University, Kowloon \\ Tang, Hong Kong, E-mail: jwang312@ hkbu.edu.hk, corresponding author.
}

doi:10.5618/arch.2012.v1.n2.6 || Received: 09-04-2012, Accepted: 01-08-2012, Available online: 03-08-2012

\begin{abstract}
The openness to marketization in China provides opportunities for artists to pursue self-expression for a new career of old buzzword of culture. Bohemian group in Beijing is the forerunner to retreat from the authoritative regime to the market system. The second attempt, represented by Beijing 798, successfully secured a respectable standing within and beyond the field of art, locally and worldwide. In Shanghai, the discourse was soon reshaped to favour creative industrial zones after renovation of abandoned plants, with its landscape devoted more to the aestheticization, frequently based on 'heritage' discovery and appropriation.
\end{abstract}

From Beijing to Shanghai, the travelling discourse on the creatives and their places in Chinese cities undergoes divergent processes, thus, generating respective products. The paper presents the evolving process of representative cases in Beijing and Shanghai with attention on actions taken by major actors: the artists, the social forces involved in the struggle to preserve the cultural clusters, and the state. It is maintained that the development of cultural cluster is indeed a product that reflects structurally biased social relations. Under this account, I attempt to explore discourses and tactics deployed by various actors and the web of interconnectedness. Whilst exploring market niche for a continuous economic growth, the state, at the same time, cautiously navigates the transformation away from politically forbidden areas.

Keywords: cultural clusters, China, the state, the bohemians, valorisation

\section{Introduction}

Chinese Contemporary Art has become the must-have item at auctions in every one of the world's art-buying capitals, such as New York, London and Hong Kong, as if their presence on the catalogue alone already guaranteed the success. It is still debated regarding whether or not Chinese contemporary art is a frenzied sector, but artworks of this category often fetched and continue to fetch several million dollars apiece. After Yue Minjun's "Execution" set a record for a Chinese contemporary work at 2.9 million pound (US\$5.9 million) in 2007, the record was soon broken by Zhang Xiaogang's "Forever Lasting Love" in 2011, which was sold for US\$10 million at Sotheby's Hong Kong auction [1]. In 2007, Chinese art made up over 70 percent of the total contemporary Asian [2]. As for buying market, China edged out France in 2007 to be the world's third-largest art market, indicating the growing wealth of Chinese society [2]. Reports above reveal great transformation in China on three dimensions: the growing army of the bohemians, the booming art market with soaring price at an unprecedented speed, and the emerging middle class with growing appetite of cultural consumption. Furthermore, the spotlight of Chinese Contemporary Art also puts another transformation in China's urban landscape into the public attention: formation of cultural clusters which evolve continuously.

All of these are accompanied with China's transition from socialist planned economy to a marketdriven economy and the constantly experimental reforms of regulatory institutions by the state. Wang Jing [3] puts 1992 as the turning point of the beginning of a "new career of old buzzword of culture" in China. In that year, the Southern Excursion Talks by Deng Xiaoping reasserted the necessity of deepening economic reform and market-oriented transition. Culture was re-evaluated and accordingly, the cultural industry sector (wenhua chanye) was officially highlighted in the "Important Strategic Decisions - Accelerating the Development of Tertiary Industry" by the State Council [4]. The state introduced the term "cultural market" in its official documents as early as 1988, and then put forward the concept of "cultural industry" in 1992. In a place where culture used to be viewed as a "propaganda" tool, the shift towards culture-as-capital indicates a gradually widened openness to marketization and privatization. Although an initial attempt was initiated right after the end of the Cultural Revolution in the socialist system [5], experimental artists were able to pursue self-expression through market device appropriation only after state policy presented opportunities. It is the introduction of market that 
prises open the socialist system of cultural production, and offers Chinese bohemians a chance to exercise freedom in cultural production, such as selfexpression or political reflection.

The forerunner is the bohemian group in Beijing [6]. To lessen the influences of the authoritative regime, they retreated to Fuyuanmen Village, a rural village adjacent to the famous Yuanmingyuan Ruins. The earlier endeavours of these Yuanmingyuan artists failed to sustain their careers in the yet-to-prosper market, or to form a habitat for themselves in the village. However, the second attempt by the bohemians, as represented by Beijing 798, successfully secured a respectable standing within and beyond the field of art, locally and worldwide. In contrast to Beijing where the place of Beijing 798 has for a long time been the solo character, Shanghai witnessed a blossoming of creative zones across the whole city in a short period [7, 8]. Inspired by the conservation campaign at Beijing 798, the changing landscape in Shanghai was devoted more to the aesthetification of the built environment, shifting to a fever of heritage discovery and appropriation. Moving from Red House to M50, Shanghai bohemians seemed to follow the same pattern as the pioneers in Beijing; some others, mostly photographers and fashion designers, opened their shops in Tianzifang and were soon joined by cafes and restaurants "selling" an exotic air that is appealing to foreign expatriates. The Municipal Planning Department renovated an abandoned workshop for Shanghai Sculpture Space, and the recently discovered historic slaughter house became the model project to demonstrate the transformation towards a high-end cultural consumption location.

From Beijing to Shanghai, the travelling discourse on the creatives and cultural clusters in Chinese cities undergoes divergent processes, thus, generating respective products. From an exclusive artists' village to a fashion arena in public imagery, the cultural clusters serves as a means through which we might decipher the historical transformation of the sociocultural landscape from its formulation, its growing recognition within and beyond the culture field, and for many times, its valorisation.

The paper presents the evolving process of representative cases in Beijing and Shanghai with attention on actions taken by major actors: the artists, the social forces involved in the struggle to preserve the cultural clusters, and the state. It is maintained that the development of cultural cluster is indeed a product that reflects structurally biased social relations. Under this account, I attempt to explore discourses and tactics deployed by various actors and the web of interconnectedness. The prevailing power of the state is by no means diminishing. Instead, power is rescaled and decentralized vertically and horizontally, driven by their entrepreneurial inclinations stemming from the local economic and political contexts. Whilst exploring market niche for a continuous economic growth, the state, at the same time, cautiously navigates the transformation away from politically forbidden areas.

Data deployed in this paper are collected by questionnaires, interviews and non-participating observations on site, supplemented by secondary data collected from government documents and archives, annual reports of consultative firm and newspaper articles. A small team of two persons were formed to conduct two rounds of interview for each city. Data collection for cases in Beijing lasted one year from 2007 to 2008, and data collections for case in Shanghai were carried out in 2008 and 2012, lasting five months and one month respectively. Openedended questions are designed. Most interviews last 2 hours each, for some cases, discussions with interviewees last 3-4 hours.

From 2007 to 2012, we interviewed more than 72 people representing different sectors. In the following section, the debates in literature are addressed first, followed by the analyses of varying power restructuring and space reconfiguration in Beijing and Shanghai. Conclusions are found at the end of the paper.

\section{Literature review}

Since the introduction of "spatial turn" in the 1980s, it has been established that space is a situated product of social process, serving the implementation and consolidation of social interests [9, 10]. Being one special type of space production, cultural spatial development is by no means a deviate form of the rule of social relations, but perhaps "a variation" of a wider order of structure. From political point of view, the cultural cluster is an amalgamation collectively shaped by various actors for struggles over resources.

According to Bourdieu [11], the meaning of a field is contested by a wide range of actors before a clear social spatial boundary is defined. The discourse on cultural industry and creative class through the union of symbolic representation and social practice [12] shapes its "objects of observation, calculation, and governance" [13]. In its core, cultural cluster is still an output of social relations; the difference is that terminology in policy and typology of cultural cluster become means to justifying the interest of different actors involved. In this account, each typology of imagined culture, cultural (creative) economy, and/or cultural city, defined and promoted by various actors are combinations of elements that are purposely selected from the pool of all elements. The configuration in terms of what are selected whilst what are left out serves to couple benefits and respective actors and agents, and to decouple benefits 
and other actors simultaneously.

The boundary of the "field" of culture has always been contested, so is that for cultural industry/industries. Debates can be traced back to the Frankfort School [14], which coined the concept of Culture Industry to describe how art and culture, which used to be practiced in a tailored aura, was installed on Fordist production lines, that is, converted to standardized products without enlightenment value. Studies on pop culture in the UK, nevertheless, maintain that massively produced culture might serves as hotbed for free expression and spur social and political reflections as well [53]. Massive attention on culture as new economy surges in late capitalist societies, many of which are in search for new directions to replace the decaying manufactory industries.

It is in this context that economists introduce the term of cultural industry or cultural industries as a promising industrial sector, the boundary of which is widely expanded. In general, cultural industry/ industries include(s) film production, publishing and fashion, in addition to orthodox ones like art and literature. In the following years, other terms are introduced to revise the boundary of cultural industries constantly, such as the creative industries with the IT sector added, and to knowledge industry that includes bio-medical industrial sectors $[15,16]$.

Basically, economists look into economic logic to explain the clustering and the synergies of culture, technology and commerce as a new economy [17]. Inspired by cases of culture-led urban renaissance like Bilbao, many mayors and decision makers detect the robust power of culture in urban regeneration. Cultural making of cities is engineered worldwide, exemplified by high profile examples like the "European City of Culture" by the EU and "Creative City network" by UESCO. Florida's advocates of creative city [18] soon gain popularity. According to his thesis, it is vital for a city to attract the creative class in a fierce inter-city competition for mobile capital at the global level. That said, strategies of making a creative city is to reshape urban landscape in accordance with the preferences of the creative class [19]. The wave of tailoring space for the creatives, however, may only squeeze artists away to make space for the affluent class, as worried by urban sociologists. Rising rent displaces not only artists but also creative professionals [20, 21]. Given this issue, questions are raised regarding the politics involved in the formation of creative groups and their spaces: what is considered creative or innovative and who is benefiting from this process $[22,23]$ ? These placesonce bohemian clusters - are commoditized or emulated, then transformed into habitats for wealthy Bobos (bohemian bourgeois) [20, 21, 24].

\section{The evolving cultural clusters in Beijing and Shanghai.}

Since the year 1271 when Kublai Khan selected Beijing to be the capital of his empire, this city has retained its status as the political center of China through all the dynasties that followed. It is not surprising then why, crossing the lengthy historical spectrum, the culture of Beijing has always been stamped with orthodoxy, classicism, solemnity, aristocratism, authoritativeness, and bureaucracy [2527]. The Beijing School, the genre specified for the culture of Beijing, naturally inherits and also functions to sustain the value of hierarchy, orthodoxy, and classicism. In comparison, Shanghai is a metropolis whose urbanization process was accompanied by commercialization and a fusion of a wide variety of forces and population segments. The semi-feudal and semi-colonial characteristic of that time played an important role in forming the so-called "Haipai" culture (literally sea-culture or Shanghai School), which roughly outlined the fusion of Western and Eastern cultures, as well as a joint culture of varying domestic traditions [28]. Continuous absorption of, and prompt adaption to, the market demands were the second character of the sea culture in this marketdriven city [29]. These differences between the two schools seemed to fade away after the new country was established. Afterwards, the socialist principles overtopped everything. Culture, as a tool of propaganda, was planned and closely watched by the machinery of state apparatus.

\subsection{The bohemians' attempt}

3.1.1 Island of the bohemians on the sea of socialist society. It is also in 1992 — when the state mouthpiece, China Youth Daily, reported the Yuanmingyuan Artist Village, a community where many transient artists congregated [30]. Behind this commune was a ground-breaking action, signifying the rebellion of artists against the socialist authoritarian system, and more importantly, a change of power dynamics in the field of cultural production, with the assistance of market.

During the socialist period, the fundamental objective of culture was to contribute a right political attitude that would convey the appropriate values worldview, and thus the way of life to the public [3]. The focus on ideology pulls culture away from the modernization of a society characterized by industrialization and commodification. Production and delivery of the politically correct cultural products was realized through the vertically hierarchical section of culture (Tiaotiao). In this section, cultural institutes of different importance and sizes were set up at difference levels, from the central, to provincial, city and county level. Classified as social organizations (Shiye Danwei), cultural institutes are financially dependent on public funding and are under the direct 
supervision of the Ministry of Culture. All artists, commonly referred to as cultural workers (wenhua gongzuozhe), were employed in cultural institutions. Normally, the cultural production started with a predetermined theme commended by a superior body for social functions like congresses and/or celebration of particular days or events. The commissioned artworks, after accomplishment, were often exhibited as parts of an official event. For the purpose of portraying an important person, such as Mao Zedong, or illustrating scenes of ordinary working folks, the genre of Russian realistic painting is nearly the only style encouraged for its effectiveness in events illustration (interviews, 2007-2008).

Still, new thinking and new genres in the West managed to penetrate into the strictly controlled cultural sector, probably through universities [3]. Tension between art and politics became slack to a certain extent since the 1980s. A series of cultural exchanges were carried out in universities, from inviting foreign artists to exhibit their works to people's actively exploring the Western world to study. The rise of the art market is another factor that gives artists hope of financial independence and therefore freedom in artistic production. The so-called 85 Youth Art Movement recorded a series of selforganized exhibitions across the whole nation, from which emerged many bohemian artists with difference voices [5].

In the 1980s, resistance against this politically controlled environment of art production began to brew, driving the group of graduates from the Central Academy of Fine Arts (CAFA) to give up their officially assigned jobs to become independent artists. Fresh graduates soon departed for Fuyuanmen Village adjacent to the ruins of Yuanmingyuan, and began their "bohemian" lifestyles[31]. The decision of the artists excluded them from the then-dominating danwei system, the basic unit in management of production and consumption in the socialist city. They had no hukou registered with the village, the institution that determines access to social welfare endowment. The new breed of artists neither received salary nor were they eligible for any social welfare. They were literally marginal in the socialist society.

In this context, the Yuanmingyuan Village transformed to an isolated island on the sea of socialist city, tangibly and intangibly [31]. Its remote location made these experimental artists feel as though they had escaped from the city and thus, from the thendominating bureaucratic system. For a long time, the existence of this village was known within the artist circles only. The remoteness of the village means relatively a less urbanized state and thus a low living cost, which was crucial for the survival of these struggling bohemians. Artists here worried more about next meal and appreciated a 12-inch black-and-white
TV set, which was considered a luxury item [30]. The only additions to the houses in the existing village were signs with the artists' names outside each door, indicating a rudimental awareness of self-management in a market setting. By no means had they lived in a way that ordinary people did at that time. Most of them are male bohemians with no families; meanwhile they frequently shared meat and alcohol together whenever one of them made some money by selling their work. The rise of art market at that time, no matter how immature, makes it possible for artists to form a kind of kingdom of their own, where freedom of expression in artistic production can be realized.

Financially, they relied purely on the art market, which had yet to prosper. It was nearly impossible for them to have their works exhibited as all galleries and museums belong to the social cultural sector, especially when the early art groups focused on the Cultural Revolution themes and protested the government with their brushes. They therefore depended enormously on individual networks, friends, and peers to find customers. Foreigners, usually those working in foreign embassies, were their main clients [6]. This might explain why commercial spaces, such as hotels, restaurants, and pubs, which foreigners frequent, were mainly targeted as exhibition venues. The first exploration towards the art market was harsh, possibly because of the extremely limited channels through which artists get their works publicized.

The existence of Yuanmingyuan Artists Village challenged the nerve of the government, which "persuaded" all artists to leave by police force in 1996. Spatially, this group with alternative opinions dispersed. Some went back to their hometowns, others went overseas. However, the rise in popularity of Chinese art in the global art field has become phenomenal after many artists immigrated and began to reflect on circumstances in China from afar.

It is about six year later when a second attempt was made by artists in Beijing 798 to deliberately secure a cluster for their own. This time, artists, dealers, galleries, art critics, art fairs and biennales are interwoven into a tight network, which resembles the Western model for an artist ecology [32, 33]. Many artists who went to the abandoned workshops in factory 798 were established "sea-turtles" (overseas Chinese who return to China) who have achieved international fame before coming back home and claiming reputation. Their stay in overseas countries armed them with knowledge on market operations and networking with galleries, as well as lessons learned from art-led regeneration trends that have swept many cities. An entrepreneurial spirit was an obvious attribute that distinguished tenant artists in Beijing 798. Realizing the importance of proximity to galleries, Huang Rui [30] contacted his friend Yukito Tabata, the Director of Tokyo Gallery, right after his 
move back to Beijing, a decision that ended his 17 year stay in Japan. At that time, Tabata intended to open a gallery in Shanghai but was caught in lengthy and complicated administrative procedures. Huang successfully persuaded Tabata that Beijing 798 was a good location. In March 2001, the "Tokyo gallery+BTAP" was launched, hosting its first exhibition, "Beijing Ukiyo-e," immediately attracting attention from artists. This event was the turning point for 798, which currently experiences growing incoming tenant traffic. Other important figure were the individual curators, many of whom were trained in art history and now work in editorial houses for art magazines or hold professorship in arts. Some of the curators were established artists themselves. Being well established in the field, curators normally enjoyed a distinguished image and possessed a wide network. Exhibitions and art fairs were organized extensively in Beijing 798. In 2003 alone, five public exhibitions were held: the first Performance Art Festival of "Trans-border Language", "Reconstruction [of] 798", "Blue Skies Exposure-Anti-SAS Exhibition", the "First 798 Biennale", and "Left Hand Right Hand." Renowned artists-curators from 798 were more effective at managing and expanding their social networks.

3.1.2 Shanghai -artists dissolving into the mundane setting. In comparison, stories of Shanghai artistic clusters are far less dramatic. First of all, artists in Shanghai are comparatively limited in quantity and they are less organized to form a social force. Secondly, the characteristics of Shanghai School, namely, the readiness and capability of continuous absorption of and prompt adaption to the market demands, seem to still be valid in illustrating features of this generation.

In 2000, the state-run Shanghai Art Shanghai Museum hosted the city's third Biennale, which was an unprecedented event marking the official endorsement of Contemporary Art in China. According to $\mathrm{Wu}$ Hong, this event deserves a place in the history of art development in China for two reasons: the introduction of curatorship mechanism and the genre of artworks exhibited. For the first time, international curators (Hou Hanru from France and Toshio Shimizu from Japan), rather than officials in the authoritarian regime, were introduced to the museum in charge of seeking and selecting representative artists for the Biennale [34]. Also for the first time, works in Contemporary Art like Pop Art, Kitsch Art and Installation Art appeared in an official exhibition. The historical event attracted huge amounts of artists, putting Shanghai under the spotlight of the entire nation. However, when the exhibition was over, the city returned to its quiet life as most artists were coming from other places of the country and merely stayed here for the exhibition. The figure of more than 500 artists in Shanghai plummeted when most of them left the city [35]. The Shanghai Third Biennale unravels an unpleasant truth - that the city has little evidence to claim a substantial segment of contemporary artists.

Furthermore, in many cases, it might be fair to comment that Shanghai artists tend to market-driven and frequently deal with triviality. In other words, their work might give priority to accommodating market needs rather than making political statement. Chen Yifei is probably one of the most well-known artists in Shanghai. Chen built a reputation in New York for his artworks that fuse the beauty of traditional Chinese ladies and the western classic style of portray painting. His work was highly praised by Armand Hammerthe, an industrialist and owner of Hammer Galleries. "Realizing that his artistic reputation could be leveraged into something bigger, he went back to China" [36]. Chen soon espoused a wide-ranging field - from clothing label, home furnishings line, a fashion magazine, and a modeling agency, to the production of two commercial movies. Chen is probably the first established artist who rent a room from the middleman of $\mathrm{Wu}$ Meiseng in the traditional residential block of Tianzifang in 1992, for "artists never like to exclude themselves from the vulgar and mundane lives of the common populace (xiaoshimin)" (interviews, 2008). Following him is Er Dongshen, another established photographer. The two big names lend romantic air to the deteriorating Lilong houses, rendering the area a rosy aura that combines artistry and triviality. Soon this place overtopped another well-known wine-and-dine place of Xintiandi for only the former reveals the real trivial life of Shanghai and thus is the place to explore the ethos of "being Shanghainess". Evidently, the strategy adopted by these middlemen of Wu Meiseng and Gao Yang, who planned to tailor the space for foreign expatriates based on their living experience abroad, has been proved to be effective. A large proportion of artists who moved in are photographers and designers who work on small scale works, converting space here to be shops that sell designed products, postcards, photos and so on (interviews, 2008).

The other cultural cluster at the earlier stage is M50, a factory-turned art cluster in Shanghai. Since the early 1990s, a group of ten artists clustered in an abandoned warehouse known as red-house [37, 6]. This is the pioneer group of bohemians who later moved to M50 after the demolishment of red house. Compared with their counterparts in Beijing, these Shanghai artists managed to secure a stable income through contracting with art galleries. In eyes of the landlord, that is, the factory manager, these artists are desirable tenants because "they always pay rent on time, they are educated people, they are intellectuals... unlike those vendors whom we used to rent our warehouse, they are polite, they dress up properly, they don't liter nor do they spit..." 
(Interviews, 2008). The reason why they rent space in the factory is partially the same to that of their peers in Beijing 798 - factories are spatial for production of large artworks. Meanwhile, selecting a factory that is located right in the central city seems to resonate with findings on art clusters in the West - for the proximity to the market. Except those pioneer ones, artists who moved in later have paid high rents in hopes of establishing their own image and gaining access to the M50 and Tianzifang networks. Again, artists in Shanghai bear more in mind the needs of ordinary populace, who make up the bulk of their customers. Artist Mu Yafeng explained: "Space here (Tianzifang) is small in size and thus more affordable, but it is also large enough for us as we normally draw small size paintings that sell more easily in the market" (Interview, 2008). Another artist offers oil-paintinglike imitations by processing customers' photos on a computer for real oil-painting is much more expensive.

3.2 Negotiations and struggles - political power of various actors and their discourses

3.2.1 Beijing - the dual role of artists. For artists, their problems were not limited to finding individuals a position in the arts industry, but encompass the issue of establishing a position that defines a collective identity as well. The proactive actions of artists, although influential, still lacked the power to secure a promising future for 798. Threatened by the factor owner, the State-owned Seven-Star Corporation, which planned to demolish the entire compound for construction of High-tech industrial park, artists searched for and appropriate various kinds of social forces. Acknowledgement by the state remains an important factor; ultimately, what would work depends largely on political connections.

The most convenient ones might be those artists who work in the system, that is, authorities in the official cultural sector. Since the 1990s, decentralization of power has provided a little room for an egalitarian atmosphere to take root. The National People's Congress finally began to veer away from the typical role of being a rubber stamp. Many other individuals not involved in government, usually renowned scholars, entrepreneurs of large profitable corporations, and representatives from different sectors, acquired opportunities to actively participate in decision-making. Although a completely democratic atmosphere remains an aspiration, what is important is that a number of elites have established their political connections through the administrative services of the hierarchical administrative system in China. The dual character of a university, i.e., being a politically controlled social organization whilst adopting certain receptiveness to cutting-edge ideological influences from overseas, provided a grey area in which artists were afforded leeway to engage in genuine artistry amidst state restrictions.

Li Xiangqun is somehow like a spokesman for Beijing 798 when the landlord tended to demolish the entire compound [31]. He was amongst the pioneer artists moving into Beijing 798 in the late 1990s and meanwhile a professor at the School of Fine Arts at Tsinghua University. In 2004, Li was elected Deputy Member of Beijing Municipal People's Congress (BMPC), the highest state body and the only legislative house in Beijing. At the annual conference of BMPC, Li submitted a bill to congress calling for "an immediate suspension of the planned large-scale destruction". Interestingly, the artists were aware that the art sector itself barely attracted sufficient attention, and thus elaborated on key issues that would to preserve the compound. The bill presented five issue perspectives, namely, scientific, historical, cultural, economic, and potential impact on the forthcoming Beijing Olympic Games. To prepare for the bill, artists expended time to uncover the history of the compound and labeled it as one of the few existing Bauhaus building clusters in Beijing. At the same time, the bill reminded the committee that demolishing a location that has been widely publicized in international media might bring about consequences for the forthcoming Beijing Olympic Games. One month later, the bill was approved.

Aside from engaging artists in the system, nearly equally concentrated efforts were accorded to social events that purposefully targeted foreign politicians, celebrities, and royalty [30, 38, 39]. The intimate relationship between artists and embassy members established in the Yuanmingyuan period was then characterized as more than merely a producer-client association. Since 2001, the place of Beijing 798 has been populated with important political figures. For instance, from 2003 to 2004, Beijing 798 welcomes visitor like French musician, Jean-Michel Jarre, thenMinister of Culture for France, Jean-Jacques Aillagon, European Union's Commissioner on Culture and Education, Ms. Vivienne Reding, France's Minister of Culture, Renaud Donnedieu de Vabres, and the former German President, Gerhard Schroeder. The media began to direct its spotlight on Beijing 798. Beginning 2003, news about 798 eventually reached audiences abroad and appeared in overseas media, such as the New York Times and South China Post. Frequent appearances in public media were a sign of the transformation of the artists themselves, from being considered "escapees from the city" to proactively seeking selective public exposure, particularly through channels possessing international influence. These high exposure to the world offers artists in Beijing 798 an effective tool in the battle again demolishment.

Behind these visible forces, the invisible hand of global art market might be one fundamental force that works from afar. Since 1980s, the early immigrated 
generation has attracted attention by their 'identity art' on political reflection of circumstances of China. Chinese art has become one important item on the West's curatorial agenda and the popularity of Chinese art in the global art market simply surged ever since. Furthermore, the arrival of China on the international art scene is all the more noticeable in the particularly buoyant and competitive contemporary art market. Recent reports by Artprice [2] note the booming art market for China, the price levels of contemporary Chinese artists having increased by $780 \%$ since 2001 . In 2007, Chinese art made up over 70 per cent of the total contemporary Asian. In the same year, there were no fewer than 36 Chinese artists in the Artprice ranking of the 100 leading contemporary artists by sale proceeds, with the unbelievably meteoric Zhang Xiogang in second place ahead of Jeff Koons. Art market observers used to comment that the contemporary art market in China was more a global one as most buyers are foreigners. Now, the international attention has stimulated the development of the local art market, which has also resulted in an investment fever in China, linked to the increasing wealth of Chinese society [40, 41].

When Chinese Contemporary Art becomes eyecatching items on the catalogue of auction houses, Chinese contemporary artists make their presence hardly ignorable. The high commercial value serves as one trigger for the shifting attitude of the government, which realizes the potential of cultural industry and soft power. In the struggle with the factory owner, it is the network that interweaves together political connections of various actors that empowered the artists. Nevertheless, the booming art market which indicates the great economic value promised by artists and the new economy of cultural industry might suggest an inevitable shift.

3.2.2 Shanghai - the mercy of land-oriented groups. In Shanghai, the same strategy of leveraging private political connections was also practiced, but these were carried out by agencies. Major actors in this process are land-oriented groups, including conservationists, planners, landlords, officials in relevant street offices, and developers that specified in cultural spatial development. It is these land-oriented groups who largely reshape the city's culture geography.

Thanks to the citizens' nostalgia towards the city's colonial past and the landmark project of Xintiandi which has provided a valuable lesson on the commercial value of history, heritage conservation becomes an bargaining chip in urban development projects [42]. Facing the similar threat of demolishment, a concerted effort was made by tenant artists in M50 and Tianzifang, together with factory manager of M50 and street officer of Tianzifang, to seek help from conservationists (interviews, 2008,
2012). Ruan Yisan, the leading professor in Historic City Planning at Tongji University, was consulted to develop the conservation plans for both two cases (interviews, 2008, 2012). Ruan acquired the nickname "Heritage Warrior" after saving a number of historic towns, many of which are now recognized as UNESCO World Heritage Sites. Ruan is also probably the first scholar who realized the power of political connections. His profession as town planner afforded him numerous opportunities to communicate with officials of planning departments at all administrative levels, many of who were his students. Comments and notes from the supervising institutions, many at the central or provincial levels, guaranteed full implementation of Ruan's conservation-driven planning.

Similar strategies were reemployed in M50 and Tianzifang, which were then branded as industrial heritage sites, a heated debate that elicited attention from the global heritage conservation field. After searching archives on the factory of M50, the Ruan team found that the original owner of the factory, which was built before 1949, was one of the Hui Entrepreneurs $^{1}$, the renowned group of merchants founded during the Jing Dynasty (interview, 2009). The history was then capitalized on to brand the factory as a "historic and cultural landscape." Under this light, as explained by the proposal, the idea of preserving the factory is to preserve cultural landscape, which is one typology in the big family of landscape. This is indeed an action to implement what has been planned, because this area is planned as an open landscape along Suzhou Creek in the Comprehensive Plan of Shanghai. Ruan presented this advocacy to his colleague, Wu Jiang ${ }^{2}$, for several times. The repeated persuasion and negotiations, coupled with the artists' discussions with embassy friends, eventually leading to a private visit by thenMayor Han Zheng in 2005. Shortly, the Shanghai Economic Committee granted the factory the distinction of a "cultural industrial agglomeration zone".

3.3 State action - policies and its implementation. In China, the art market boomed during a transient era, when the country witnesses several parallel processes: the transformation to market economy with macro-level monitoring, the shift to consumerismdriven society and the emergence of New Rich, and experimental reform of former socialist institutions that is constantly re-interpreted by the state. As Wang

\footnotetext{
${ }^{1}$ Hui Entrepreneurs distinguished themselves from other businessmen through strong cultural competencies.
}

2 In 2003, Wu Jiang, professor in Architectural History at Tongji University, was appointed Deputy Head of the Shanghai Municipal Planning Bureau and assumed responsibility over historical sites. 
insightfully puts, "a leisure culture campaign was not a mere discursive event built in a vacuum"; rather, it is "culture as leisure" and is "first and foremost an official discourse born from calculated state policy" [3]. The agglomeration of artists in Yuanmingyuan, Beijing 798, and M50 deviated from the central plan that purposively highlights the entertainment function of culture whilst avoiding other aspects of ideological reflection. The bohemian pioneers who attempted to criticize society experienced harsh recourse at the beginning, but the situation changed when prices of artworks skyrocketed in auctions. Moreover, the intensely arranged exhibitions of experimental arts inadvertently led to the popularity of Beijing 798 among ordinary populace, in whose eyes the term "bohemian" eventually takes no hint of unorthodoxy or irony, but fancy way of life. The state soon modified its attitude and promptly revised its plan accordingly to accelerate economic restructuring.

At the annual National People's Congress of 2006, both cities presented their blueprints for building creative cities. Beijing officially adopted the Cultural and Creative Industry as the city development strategy for the first time, depicting a vision wherein the city will be transformed into a national creative locality by 2010. The municipal government of Shanghai was even more aggressive at the annual congress. According to their report, the city will attempt to become one of the most influential Centers of Creative Industry in Asia in 10 years and subsequently, one of the most influential Centers of Creative Industry in the world in 20 years.

Despite of the great potential of capitalizing art, the state's sceptical attitude towards the political implications of art hardly changes. The objectives and themes on cultural industry development always revolved around leisure consumption by the general public. This is demonstrated by a series of campaigns at the national level, such as the Cultural Long March Program (wenhua changzheng), which intended to present shows and performances to all towns and counties. The official cultural creative industries include nine sectors: art performances, publications and copyright trade, film and TV production and transactions, animation and network gaming, cultural conventions and exhibitions, and antique and art articles transactions, creative design, cultural tourism, and cultural and sport industry [43]. As such, the official definition of cultural industries reveals that preferential politics are mostly favourable for television, film, and publishing enterprises, which offer massive amusement whist promise instant profit. As such, it is worthwhile to note how the different government departments take lead in further developing cultural clusters in the two cities. In Beijing, action was led by the Tourism Department, acknowledging the potential to expand the appeal of the city by incorporating contemporary culture. In
Shanghai, the authority of Economic Reforming Committee was established, to promote the reuse of abandoned industrial sites in the inner city as creative industrial centers whilst publish incentives for real estate developers.

3.3.1 Capitalizing the tourists' gaze. According to the working procedure of the BMPC, approved bills are submitted to the municipal government, which then disseminates the bill to appropriate departments. The department designated to handle the bill earlier presented by Li Xiangqun was the Municipal Tourism Department [30]. Governments across the world are now seizing on the marketing and tourist potential of contemporary art and the Chinese are no exception. The potential of Beijing 798 to engaze tourists, particularly foreign tourists, has provided the municipal government numerous inspirations [39]. In 2005, the Beijing Municipal Tourism Bureau published its research report on Beijing 798 and suggested the resolution of "Cultural Tourism and Consumption Zone". In 2006, intervention from the Beijing 798 Art Zone Administration and Development Office completed the shift from exclusivity to hospitality.

In contrast to the previous small, fragmented, and particular interventions employed to save individual buildings, overall renovation was planned and designed to clearly target entrances and public spaces. Parking lots were expanded and roads were repaved. Infrastructure and facilities, such as street lights, greenery, telephone and fire exit systems, and security equipment were upgraded. Signage and boards were erected at every street corner. At the opening of the Beijing Olympic Games, Chen Gang, General Secretary of the Chaoyang District Government, introduced his slogan "Beijing - The Great Wall, Peking Duck, and 798!" [39]. Beijing 798 is listed on the tourist brochure as one of the must-sees when you visit Beijing for the experience of the hot art scene in China. Thousands of tourists were lured in the place daily, and the total number of visitors reached 1.5 million in 2007 alone. The number of visitors rose to more than 10,000 per day during the Olympic Games, among them from many important personalities. Security guards working in 798 proudly claimed, "I met three presidents in a single day" [44].

However, in opposition to the flourishing of artrelated commercial companies, tourists, and vendors, artists initiated a wave of retreat. As early as 2004, the pioneer Sui Jianguo moved out of 798. Three years later, Huang Rui left as well. Apart from the criticism that the district became "more a show than serious art," another fundamental factor dispelled artists' interests were the rising rent, which ranged from 2 to 7 RMB per square meters per day - more than double than 2002 values (interviews, 2007-2008). Another aggravating factor was the increasing number of 
tourists. The attention of the general public, which used to be actively sought and appropriated by artists during the petition against the demolition of 798 , became a burden. As recourse, the artists once again shut their doors and turned their backs on the public.

3.3.2 Property-driven development. In Shanghai, conservationists' discourse of heritage conservation is hardly built up on solid evidence, but the government seemed to find the proposal reasonable. In this case, the real temptation, as argued by the author, might be a new model of property development that government detects to continue the land-oriented growth after the pervious way becomes less productive for two reasons: the large quantities of empty manufactory sites with many constraints that make the previous model less applicable, and the notorious sector of real estate which was excluded out of the five-year plan due to massive complains against housing affordability [7].

After closing, terminating production in, merging or transforming polluting enterprises in the inner city in the 1990s, the municipal government was later incidentally burdened by the slowly decaying mammoth structures. With scarce availability of lands in the inner city, these structures particularly became a stumbling block to a much-needed influx of mobile capital. Following years of experimental exploration, the Shanghai Municipal Economic and Information Technology Committee proposed the programme of the Creative Industrial Agglomeration Zone, a cluster that restores and reuses industrial legacies to accommodate creativity-based firms [45]. This concept of urban landscape aestheticization for overseas investments was again adopted. In contrast to previous practices, such as the Hongqiao and Pudong New District, the challenge is the presence of almost hundreds of industrial sites that are scattered across the metropolis. These structures differ in size and shape, making them difficult to handle in an overall development manner, as what has been previously done in Hongqiao and Pudong [46, 47]. Individual developers need to be mobilized. However, such projects attracted minimal interests from developers owing to the low plot ratio and thus, low profit returns, if operated in an ordinal strategy of property development.

Meanwhile, the real estate sector was also facing exclusion from privileged sectors at that time. The year 2005 witnessed heated debates on whether the real estate sector should be retained as one of the pillar industries in the 11th Five-Year Plan. While the sector contributed to a large share of GDP, thus naturally enjoying esteem by the government, it was conversely widely attacked by the populace because of serious issues on housing affordability. In an attempt at a compromise, the government dropped the real estate sector in the five-year plan and promoted instead the cultural industry [48]. A way to re-invent the real estate sector as the incubator of the cultural industry is developed.

Making use of the dual land market system to attract developers is not a new strategy for the state [49]. In 2004, the Shanghai Creative Industry Center, a semi-governmental organization, proposed the Three Unchanging Principles to iron out legislative difficulties. Under such Principles, "ownership of Land Use Right," "nature of land use," and "the major structure of the building" have remained unchanged for renovation projects. By its very nature, the Principles has invented an informal category of rentable industrial spaces on state-owned lands, which otherwise commands land premium at market price for the transfer of land use right [50, 49]. According to the three principles, renovating old industrial buildings or compounds, which are to be transformed into creative industrial parks, can be interpreted as if the developer simply rents the space and sub-let it to others. The other two principles, unchanged building structure and unchanged land use, serve merely as evidence to demonstrate the nature of the rehabilitation project, which is a refurbishment of rented space rather than a development project on a piece of urban land [7]. The hidden incentives given to developers were soon appreciated, followed by a city-level fever of industrial sites rehabilitation. From 2006 to 2009, 80 projects were completed and were granted as "Creative Industry Agglomeration Zones".

The official promotion by the Shanghai government was responded with a city-wide wave of industrial building regeneration, with obvious concentration on the aestheticization and a frequent dependence on heritage conservation. Bridge 8 was a pioneer project led by Tony Wong, who understood from his previous experience in Xintiandi monetary value of historic symbol. The old brick walls of workshops were refabricated to form an eye-catching matrix. Buildings were connected by bridges, which were designed in various shapes and colors. The second influential project, Red Town, distinguished itself through the direct interventions of the Municipal Planning Department. Although the buildings themselves were not of high value, a high standard of restoration and preservation principles were followed to portray the fabric, particularly on the decay, as if to treat historic monuments. At precisely the right time, the old slaughter house in Hongkou District was discovered. The slaughter house, designed by British architect Balfour in 1933, used to be the largest modern slaughter house in Asia. Its architectural beauty mixes art deco with modernism to arrive at a specific function. A series of walkways that were designed to send cows to different production sections were arranged along the circular courtyard. Standing in the courtyard, one would be impressed by the interlocking walkways that cut the void space into fragmented yet 
fluent sections with dynamically changing shades and lights - a fantasy for architects. In 2005, the slaughter house was listed as the Distinctive Historic Building by the municipal government. The legitimization of its historic value provided the Shanghai Creative Industrial Center an authentic industrial heritage to work on, thus promptly triggering tremendous enthusiasm. To emphasize its important historic value, the Center coined the name "1933 Old Millfun" for the slaughter house (interviews, 2009, 2012).

Although regeneration projects were normally tailored according to the rather dubious assumption that the reuse of industrial buildings was desired by artists, artists were by no means welcomed by these offices after renovation. The market niche lay in the demands from firms that need a creative identity. But first of all, inviting big names in the creative industry to be tenants is a prerequisite for developers to selling their products, changing the projects as an avenue for fierce competition for established firms. Offices in Bridge 8 became attractive only after Hong Kong movie director $\mathrm{Ng}$ See-Yuen moved in the area. The developer of the Red Town offered space free of charge to established graphic designer, Yang Mingjie, and later offered a huge discount to Minsheng Banking for the Minsheng Modern Art Gallery. The contract with Interbrand, a famous multinational branding company, was proudly viewed as a success by the developer, who meanwhile was disappointed by ShanghArt, one of the few art galleries with firstrate reputation in the field, who rejected their generous offer (interviews, 2009). The marketing staff in 1933 Old Millfun did not bother to hide her disdain when asked to compare it and Red Town, indicating that 1933 hosted functions for more top end brands after they subcontracted property management to An Axons Concept, the agency that introduced the Armani flagship store to Shanghai (interviews, 2009). In Bridges 8, thirteen out of 45 tenants are in architectural, interior, or furniture design, seven in property management, five in fashion and accessory design, and five in business planning. In Red Town, the largest category is trading; the second largest category is architectural and graphic design; the third is shared by advertising and culture. Amongst the four tenants classified as cultural, one is a bookstore, two are educational institutes for children, and the remaining one is an art gallery. Financial capability also remains an important key factor. Of the 45 tenants in Bridge 8, thirty-four are local branches of MNCs, and four of the remaining 10 domestic firms are offices under the municipal government. In Red Town, the proportion is 17 of 28 for MNCs and domestic companies, respectively (interviews, 2009).

\section{Concluding comments}

In China, the evolution of cultural clusters runs parallel with marketization, realizing that the role of "the sovereign power" of the state is to "regulate and frame" the pursuits of disparate sectors is important [51]. The development may be better understood as part of the dynamic process where the state seeks a niche for economic development. The central state's intention is clear: develop cultural industry that incorporates certain originality to the production line for massive consumption. Emphasis is always placed on the consumption and enjoyment of the public [3, 52], while control on ideology is never relaxed. The possibility of nudging the exclusive field to a new economy that is based on massive consumption is actively sought and appropriated.

The process is dynamic and contingent on all actors proactively adjusting their strategies, derived from varying urban contexts. The travelling discourses on the creative field take on different forms because of varying historic and economic contexts, as well as differing entrepreneurial inclinations of sectional departments. In Beijing, the agglomeration of bohemian artists may hardly please the government, but the addition of galleries in the art zone makes for an hippie atmosphere attractive to the general public. Such an environment sparked countless inspirations for tourism development. In Shanghai, the renovation of antiquated buildings is advocated as creative industry incubators, surrendered to the powerful real estate sector and the prevailing property-led place making strategy.

Beijing municipal government's response disappointed avant-garde artists who overestimated the influence of 798, while in Shanghai, the policy benefits only those who "combine art, creativity and entrepreneurship" (Hutton, 2008). In both cities, the objective is closer to the nature of "culture industry," a term coined by the Frankfort School [14], the only addition is a layer of originality and inspiration as capital circulation in the late phase of consumerism has found a niche in disjunction and alternativeness. The departure from ideological reflection that might trigger any alternative thinking against the sovereign power remains unchanged. More importantly, the threshold to enter the field of "creative" is lowered, especially benefiting those who incorporate a certain level of creative ideas to mass production lines. The creative industry is so casually defined that the door is wide open to almost all knowledge-related firms or sections of MNCs to reinvent themselves-an environment that presents increased prospects for incoming capital.

\section{Acknowledgement}

The study is supported by the Faculty Research Grant at Hong Kong Baptist University, reference number: FRG2/11-12/114. 


\section{Reference}

[1] O'Dea, M. "Six Art-Market Trends to Watch in China's Fall Auction Season." Blouin ARTINFO, 12 November 2011.

[2] Artprice. 'Art Market Trends 2010.' In Art Market Trends, edited by T. Ehrmann: Artprice, 2011.

[3] Wang, J. 'Culture as Leisure and Culture as Capital.' Positions: East Asian Cultures Critique 9, no. 1 (2001): 69-104.

[4] Tuo, Z. "Transformation of Mission: Cultural Market Management in the Past 30 Years." China State Ministry of Culture, http://www.ccnt.gov.cn/sjzz/whscs/zhxw/200810/t 20081010 58412.html.

[5] Gao, M. 85 Art Movement (85 Meishu Yundong). Guizhou, China: Guangxi Normal University Press, 2007.

[6] Wang, J., and S. Li. The Rhetoric and Reality of Culture-Led Urban Regeneration - a Comparison of Beijing and Shanghai, China. New York: Nova Science Publisher, 2011.

[7] Wang, J. "Art in Capital': Shaping Distinctiveness in a Culture-Led Urban Regeneration Project in Red Town, Shanghai.' Cities 26, no. 6 (2009): 318330.

[8] Li, W., and J. Hua. 'Shanghai's Emergence into the Global Creative Economy.' In Creative Economies, Creative Cities, edited by L. Kong and J. O'Connor. 167-173. London, New York: Springer, 2009.

[9] Harvey, D. The Urban Experience. Oxford, UK: B. Blackwell, 1989.

[10] Lefebvre, H. The Production of Space. Oxford: Blackwell, 1991.

[11] Bourdieu, P., and R. Johnson. The Field of Cultural Production: Essays on Art and Literature. Cambridge: Polity Press, 1993.

[12] Zukin, S., R. Baskerville, M. Greenberg, C. Guthreau, J. Halley, M. Halling, K. Lawler, et al. 'From Coney Island to Las Vegas in the Urban Imaginary: Discursive Practices of Growth and Decline.' Urban Affairs Review 33, no. 5 (1998): 627-654.

[13] Jessop, B., and S. Oosterlynck. 'Cultural Political Economy: On Making the Cultural Turn without Falling into Soft Economic Sociology.' Geoforum 39, no. 3 (2008): 1155-1169.

[14] Horkheimer, M., and T. W. Adorno. Dialectic of Enlightenment. New York: Seabury Press, 1972.

[15] Evans, G. 'Creative Cities, Creative Spaces and Urban Policy.' Urban Studies 46, no. 5-6 (May 1, 2009 2009): 1003-1040.

[16] O'Connor, J. 'The Cultural and Creative
Industries: A Literature Review.' London: Creativity, Culture and Education, 2010.

[17] Scott, A. J. 'Capitalism and Urbanization in a New Key? The Cognitive-Cultural Dimension.' In Social Forces, 1465-1482: University of North Carolina Press, 2007.

[18] Peck, J. 'Struggling with the Creative Class.' International Journal of Urban and Regional Research 29, no. 4 (2005): 740-770.

[19] Florida, R. Who Is Your City: How the Creative Economy Is Making Where to Live the Most Important Decision of Your Life. New York: Basic Books, 2008.

[20] Lloyd, R. Neo-Bohemia: Art and Commerce in the Post-Industrial City. New York: Routledge 2006.

[21] Zukin, S. Loft Living: Culture and Capital in Urban Change. Baltimore, London: The Johns Hopkins University Press, 1982.

[22] Christopherson, S., and D. van Jaarsveld. 'New Media after the Dot.Com Bust.' International Journal of Cultural Policy 11, no. 1 (2005): 77-93.

[23] Indergaard, M. 'What to Make of New York's New Economy? The Politics of the Creative Field.' Urban Studies 46, no. 5\&6 (2009): 1063-1093.

[24] Zukin, S., V. Trujillo, P. Frase, D. Jackson, T. Recuber, and A. Walker. 'New Retail Capital and Neighborhood Change: Boutiques and Gentrification in New York City.' City and Community 8, no. 1 (2009): 47-64.

[25] Li, C. 'Rediscovering Urban Subcultures: The Contrast between Shanghai and Beijing.' The China Journal 36 (1996): 139-153.

[26] Luo, S., ed. A Critique of the Beijingnese?! (in Chinese). Beijing: China Society Press, 1994.

[27] Weston, T. B. The Power of Position: Beijing University, Intellectuals and Chinese Political Culture. Berkley and Los Angeles: University of California Press, 2004.

[28] Wu, W. 'Cultural Strategies in Shanghai: Regenerating Cosmopolitanism in an Era of Globalization.' Progress in planning 61 (2004): 159-180.

[29] Lee, L. O.-F. Shanghai Modern: The Flowering of a New Urban Culture in China, 1930-1945. London: Harvard University Press, 1999.

[30] Huang, R., ed. Beijing 798: Reflections on a "Factory" of Art. Beijing: Sichuan Publishing Group, Sichuan Fine Art Publishing House, 2008.

[31] Yang, W. "Talk About the "Yuanmingyuan Artists' Village" on the Ruin of Yuanmingyuan." SOHU News, http://yule.sohu.com/20050817/n226698747.shtml. 
[32] Markusen, A., and G. Schrock. 'The Artistic Dividend: Urban Artistic Specialisation and Economic Development Implications.' Urban Studies 43, no. 10 (2006): 1661 - 1686.

[33] Pratt, A. C. 'The Cultural Economy: A Call for Spatialized 'Production of Culture' Perspectives.' International Journal of Cultural Studies 7, no. 1 (2004): 117-128

[34] Wu, H. 'Reinventing Exhibition Spaces in China.' Museum International 53, no. 3 (2001): 19-25.

[35] —. The 2000 Shanghai Biennale: The Making of a "Historical Event" in Contemporary Chinese Art.' In Chinese Art at the Crossroads: Between Past and Future, between East and West, edited by $\mathrm{H}$. Wu. 275-285. Hong Kong: New Art Media, 2001.

[36] Darwent, C. "Chen Yifei: Painter and FilmMaker Who Became the Chinese Martha Stewart." The Independent 16 April 2005.

[37] Zhong, S. 'From Fabrics to Fine Arts: Urban Restructuring and the Formation of an Art District in Shanghai.' Critical Planning 16 (2009): 118137.

[38] Ye, Y. 'Weightlessness - 798 in the Present Continuous Tense.' In Beijing 798: Reflections on "Factory" of Art, edited by R. Huang. 26-37. Beijing: Sichuan Publishing Group, Sichuan Fine Art Publishing House, 2008.

[39] Li, Y., R. Qiu, and F. Dou. "China's New Landmark Go to the World: 798 Becomes the "Busisnes Card" of Beijing." Guangzhou Daily, 2008.

[40] Kraeussl, R., and R. Logher. 'Emerging Art Markets.' Emerging Markets Review 11, no. 4 (2010): 301-318.

[41] Wang, X. "Gallery's Role in Contemporary Chinese Art Market." The Ohio State University, 2009.

[42] Ren, X. 'Forward to the Past: Historical Preservation in Globalizing Shanghai.' City and Community 7, no. 1 (2008): 23-43.

[43] BMG (Beijing Municipal Government). 'Part
Three: Development Focus and Policy Orientation.' In The 11th Five-Year Plan of Beijing, edited by B. M. Government. Beijing, 2006.

[44] Shen, Z. ""The Great Wall, Peking Duck, 798" Debates on the Tourism Promotion of 798 Art Zone." China Tourism News, 25 August 2009.

[45] SCIC(Shanghai Creative Industry Center). "Profile." http://www.shec.gov.cn/.

[46] Wang, J., and S. S. Y. Lau. 'Forming Foreign Enclaves in Shanghai: State Action in Globalization.' Journal of Housing and the Built Environment 23, no. 2 (2008): 103-118.

[47] Olds, K. 'Globalizing Shanghai: The 'Global Intelligence Corps' and the Building of Pudong.' Cities 14, no. 2 (1997): 109-123.

[48] SHMG (Shanghai Municipal Government). Outline of the Eleventh Five-Year Plan for National Economic and Social Development in Shanghai. Edited by Shanghai Municipal Government Shanghai2006.

[49] Yeh, A. G. O., and F. Wu. 'The New Land Development Process and Urban Development in Chinese Cities.' International Journal of Urban and Regional Research 20 (1996): 330-353

[50] Zhu, J. 'From Land Use Right to Land Development Right: Institutional Change in China's Urban Development.' Urban Studies 41, no. 7 (2004): 1249-1267.

[51] Ong, A., and L. Zhang. 'Introduction: Privatizing China: Powers of the Self, Socialism from Afar.' In Privatizing China: Socialism from Afar edited by L. Zhang and A. Ong. 1-20. Ithaca and London: Cornell University Press, 2008.

[52] Wang, J. 'The State Question in Chinese Popular Cultural Studies.' Inter-Asia Cultural Studies 2, no. 1 (2001): 35-52.

[53] Morley, D., and K.-H. Chen, eds. Stuart Hall: Critical Dialogues in Cultural Studies. London and New York: Routledge, 1996. 